RAISING CHINA'S REVOLUTIONARIES

Studies of the Weatherhead East Asian Institute, Columbia University 
STUDIES OF THE WEATHERHEAD EAST ASIAN INSTITUTE, COLUMBIA UNIVERSITY

The Studies of the Weatherhead East Asian Institute of Columbia University were inaugurated in 1962 to bring to a wider public the results of significant new research on modern and contemporary East Asia. 


\title{
Raising China's
}

\section{Revolutionaries}

MODERNIZING CHILDHOOD FOR COSMOPOLITAN NATIONALISTS AND

LIBERATED COMRADES, 1920S-1950S

Margaret Mih Tillman

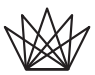 \\ Columbia University Press \\ New York
}




\section{Columbia University Press Publishers Since 1893}

New York Chichester, West Sussex cup.columbia.edu Copyright (C) 2018 Columbia University Press All rights reserved

\section{Library of Congress Cataloging-in-Publication Data}

Names:Tillman, Margaret Mih, author.

Title: Raising China's revolutionaries : modernizing childhood for cosmopolitan nationalists and liberated comrades, 1920s-1950s / Margaret Mih Tillman.

Description: New York, NY : Columbia University Press, [2018] | Series: Studies of the Weatherhead East Asian Institute, Columbia University | Includes bibliographical references and index.

Identifiers: LCCN 2018004616 (print) | LCCN 2018029545 (ebook) | ISBN 9780231546225

(electronic) | ISBN 9780231185585 (cloth : alk. paper)

Subjects: LCSH: Child rearing—China—History. | Child welfare—China—History. |

Children-China-History. | Families-China-History.

Classification: LCC HQ792.C5 (ebook) | LCC HQ792.C5 T56 2018 (print) |

DDC $362.70951-\mathrm{dc} 23$

LC record available at https://lccn.loc.gov/2018004616

Columbia University Press books are printed on permanent and durable acid-free paper.

Printed in the United States of America

Cover design: Noah Arlow

Cover image: Cover of New Children, Cotsen Children's Collection,

Princeton University Library 
For my parents, Hoyt Cleveland Tillman and Cristina Mih Tillman 

The great person is one who does not lose his childlike heart.

-Mencius

Is not the character of every epoch revived, perfectly true to nature, in the child's nature? Why should the childhood of human society, where it had obtained its most beautiful development, not exert an external charm as an age that will never return? There are ill-bred children and precocious children.

—Karl Marx, Grundrisse 
